\title{
Serum Annexin V and Anti-Annexin V levels and their relationship with metabolic parameters in patients with type 2 diabetes
}

\author{
Oktay Bilgir ${ }^{1}$ \\ Huseyin Afsin Vural ${ }^{1}$ \\ (iD) Ferda Bilgir ${ }^{2}$ \\ Ozden Yildirim Akan ${ }^{1}$ \\ (iD) Ismail Demir ${ }^{1}$
}

1. Izmir Bozyaka Training and Research Hospital, Department of Internal Medicine, Bozyaka, Izmir, Turkey. 2. Katip Celebi University Medical School, Ataturk Education and Research Hospital Department of Allergy and Immunology, Izmir, Turkey.

\section{SUMMARY}

BACKGROUND: We investigated the serum annexin $V$ and anti-annexin $V$ levels and their relationship with metabolic parameters in patients recently diagnosed type 2 diabetic.

METHODS: A total of 143 patients recently diagnosed type 2 diabetes and 133 control subjects were included in the study. Body mass index (BMI), hs-CRP, HOMA-IR, carotid intima-media thickness, and serum levels of annexin $V$ and anti-annexin $V$ were investigated.

RESULTS: HOMA-IR, serum hs-CRP, and carotid intima-media thickness were found to be statistically significant. The Pearson correlation analysis revealed a statistically significant positive relationship between the carotid intima-media thickness and the annexin $V$ level $\left(r=0.29, p=0.006^{*}\right)$. A statistically significant positive relationship was also detected between the Annexin $V$ level and level of serum hs- $\operatorname{CRP}\left(r=0.29 p=0.006^{*}\right)$.

CONCLUSION: A positive relationship was observed between the carotid intima-media thickness and annexin $V$ at the end of our investigation. In this regard, we also believe that serum levels of annexin $V$ may be increased for cardiovascular protection in the elevation of carotid intima-media thickness.

KEYWORDS: Diabetes Mellitus, Type 2. Annexin A5. Carotid Intima-Media Thickness.

\section{INTRODUCTION}

Annexin $\mathrm{V}$ is a protein known to have potent anticoagulant effects. It is also known that Annexin V plays a role in apoptosis regulation and is effective for the prevention of excessive coagulation and inflammatory activity $^{1,2}$. Anti-annexin $\mathrm{V}$ antibodies have been demonstrated in several autoimmune diseases ${ }^{3-5}$. Anti-annexin $\mathrm{V}$ antibodies are expected to lead to thrombotic and vaso-occlusive events by blocking the effects of annexin $\mathrm{V}$.

Early detection of atherosclerosis is crucial, and ultrasound imaging of the carotid arteries is a non-invasive, reliable, and easily accessible method that can give characteristic information about the carotid artery. The evaluation of the carotid artery provides 
information about the risk of coronary artery diseases such as stroke and cardiovascular disease. Many cardiovascular risk factors are known to affect the carotid artery wall. According to the American Heart Association guidelines, an evaluation of the carotid intima-media thickness is recommended as Evidence II A. Similarly, if the Framingham risk score is between $10 \%$ and $20 \%$, an evaluation of the carotid intima-media thickness of the patients without known CAD, cerebrovascular disease, and peripheral arterial disease is recommended by other guidelines ${ }^{6,7}$.

We aimed to investigate the serum annexin $\mathrm{V}$ and anti-annexin $\mathrm{V}$ levels and their relationship with metabolic parameters and carotid intima-media thickness in newly diagnosed diabetic patients. There are investigations conducted with serum annexin $\mathrm{V}$ and anti-annexin $\mathrm{V}$ levels in type 1 diabetic patients in the literature. In addition, annexin $\mathrm{V}$ and anti-annexin $\mathrm{V}$ levels have been investigated in patients with many autoimmune and inflammatory diseases, which were known to increase the tendency of thrombosis. There are also studies in which its levels were investigated in patients who had acute myocardial infarction. We aimed to investigate the relationship between serum annexin $\mathrm{V}$ and anti-annexin $\mathrm{V}$ levels and micro- and macrovascular complications of diabetes. We planned a study that would help to identify possible co-morbid conditions as well as determine the serum annexin $\mathrm{V}$ and anti-annexin $\mathrm{V}$ levels in diabetic patients at the time of diagnosis.

\section{METHODS}

Patients recently diagnosed with diabetes who were admitted to the internal medicine and endocrinology outpatient clinic were informed about the study and its objectives. A total of 143 diabetic patients were included after giving written consent. As a control group, a total of 133 healthy individuals were enrolled in the study after giving written consent. The study was designed as a cross-sectional case-control study.

The inclusion criteria were a recent diagnosis of diabetes, willingness to participate, and age between 30 and 65 years old. The exclusion criteria were pregnancy, a previous diagnose of diabetes, a history of malignancy, a history of steroid use, a history of drug use affecting the autoimmune system (Azathioprine, cyclosporine A, cyclophosphamide, quinine, TNF-alpha blockers, etc.), acute/chronic kidney failure, and acute/chronic liver disease.

\section{Patients}

Demographic information was recorded for the entire study group (age, sex, waist and hip circumference, body mass index values). Body mass index (BMI) was calculated as $\mathrm{kg} /$ height $\left(\mathrm{m}^{2}\right)$. It was obtained by dividing the weight in $\mathrm{kg}$ by the body surface area in $\mathrm{m}^{2}$. Waist and hip circumferences were measured using a measuring tape $(\mathrm{cm})$. The waist circumference was measured midway between the lower edge of the rib and the iliac spine. The blood pressure of the patients was measured at the brachial artery using Erka brand sphygmomanometer after resting for at least 10 minutes. The insulin resistance of the patients was calculated according to HOMA-IR (Homeostasis Model Assessment).

\section{Laboratory}

In both study and control groups, fasting and postprandial plasma glucose levels, as well as HbA1c levels, were measured to assess the glycemic status, fasting serum insulin, metabolic parameters as serum lipid levels (total cholesterol, HDL, LDL, triglycerides), and liver and kidney function tests (ALT, AST, urea, creatinine) to evaluate the pancreatic $\beta$-cell function. An additional 10cc of blood was drawn from the study participants to assess serum-annexin $\mathrm{V}$ and anti-annexin $\mathrm{V}$ levels in addition to blood samples taken for complete blood count, hs-CRP, serum electrolytes, and thyroid function tests.

Analysis of all blood samples was performed in the Biochemistry Laboratory of Izmir Bozyaka Training and Research Hospital. The venous blood of the patient and control groups was drawn into $8 \mathrm{ml}$ vacuumed tubes with gel separator (Vacuette, Greiner Bio-One, Austria) after an average of 10 hours fasting. The blood samples were centrifuged at 3,000 rpm for 10 minutes at room temperature after waiting about 30 minutes for clotting. Some of the serums obtained were used for routine biochemical analysis. Routine biochemical tests were performed with biochemistry autoanalyzer using commercially available kits by standard methods (Olympus 2700, Olympus Optical Co. Ltd, Shizuoka-ken, Japan). The remaining serum was portioned and stored at -800C until the Human Annex V, and anti-Annexin $\mathrm{V}$ levels were studied.

\section{Annexin $\mathrm{V}$ and Anti-Annexin $\mathrm{V}$}

A commercial kit (eBioscience, North America) which works with the ELISA method was used for serum Annex V and anti-Annexin V levels. Studies 
were carried out according to the instructions in the kit. The spectrophotometric measurement was made with Thermo Scientific Multiskan GO models ELISA reader (Finland) at $620 \mathrm{~nm}$ wavelength. Anti-Annexin $\mathrm{V}$ and Annexin $\mathrm{V}$ concentrations of the samples were determined by the standard curve drawn using dilute standard absorbance. The results were expressed in $\mathrm{ng} / \mathrm{ml}$.

Carotid intima-media thickness was measured at the Radiology Clinic of our hospital, using Hitachi Ultrasound and by the same physician in order to ensure standardization. The patient was placed in the supine position with the neck slightly extended, and the head turned contralateral to the side for the measurement. A grayscale examination was carried out using a 13.6 MHz probe during the investigation. The grayscale investigation was started in the transverse projection. The examination was performed to include the entire cervical carotid artery, from the supraclavicular notch to the angle of mandible on both sides. In our study, the measurement of both carotid arteries was taken. Intima-media thickness was defined as the distance from the lumen intima interface to the media adventitia interface. B-mode US measurements of the extracranial vascular structures were performed in regions without plaque. Intima-media thickness was measured in the thickest part of the bilateral carotid arteries.

\section{Statistical Analysis}

All analyses were performed using the Statistical Package for the Social Sciences software version 21.0 (SPSS Inc., Chicago, USA) software. The distribution of continuous variables was done using the Kolmogorov-Smirnov test, and all continuous variables were found to be normally distributed ( $p>0.05$ ). The results of continuous variables were expressed as mean \pm standard error. The demographic and laboratory data of diabetic individuals and individuals with normal glucose tolerance were obtained using an independent t-test. The relationship between Annexin V, Anti-Annexin $\mathrm{V}$, and other demographic and laboratory data was analyzed using the Pearson correlation analysis. Multiple linear regression analysis was performed on the independent relationship between Annexin V, Anti-Annexin V, and other variables. The co-occurrence of Klotho and diabetes was also investigated with binary logic regression analysis. $\mathrm{P}<0.05$ was considered statistically significant in our study.

\section{RESULTS}

A total of 143 patients, aged 30-65 years, with newly diagnosed diabetes who were admitted to the internal medicine and endocrinology outpatient clinic between October 2014 and January 2018 and a total of 133 healthy controls of equivalent age were enrolled in the study. The comparison of demographic, anthropometric, radiological, and laboratory findings of newly diagnosed DM and control groups are presented in the Table. No statistically significant difference was observed regarding age, BMI average, and sex distribution between two groups ( $p>0.05)$. The waist circumference was significantly higher in the group of the newly diagnosed diabetes $(\mathrm{T} 2 \mathrm{DM}=99.34 \pm 10.54 \mathrm{~cm}$, Control $\left.=91.37 \pm 11.63 \mathrm{~cm}, p=0.001^{*}\right)$. No statistically significant difference was observed in terms of systolic and diastolic blood pressures between the two groups (T2 DM=116.97 $\pm 9.82 \mathrm{mmHg}$, Control $=114.65 \pm 16.08$ $\mathrm{mmHg}, \mathrm{p}=0.421$ and $\mathrm{T} 2 \mathrm{DM}=71.62 \pm 6.42 \mathrm{mmHg}$, Control=70.46 $\pm 11.53 \mathrm{mmHg}, \mathrm{p}=0.566$ respectively). The carotid intima-media thickness was significantly higher in the newly diagnosed group (T2 DM=0.81 \pm 0.19 , Control $=0.67 \pm 0.11, p<0.001)$.

Serum hs-CRP (T2DM=6.62 $\pm 5.98 \mathrm{mg} / \mathrm{dL}$, Control $\left.=4.08 \pm 4.29 \mathrm{mg} / \mathrm{dL}, \mathrm{p}=0.027^{*}\right)$ and HOMA-IR $\left(\mathrm{T} 2 \mathrm{DM}=10.06 \pm 16.04\right.$, Control $\left.=1.70 \pm 1.44, \mathrm{p}=0.002^{*}\right)$ levels detected were significantly higher in diabetic patients than in the individuals in the control group.

No statistically significant difference was observed in terms of renal functions (creatinine) between the two groups (T2 DM= $0.90 \pm 0.16 \mathrm{mg} / \mathrm{dL}$, Control $=0.88 \pm 0.17 \mathrm{mg} / \mathrm{dL}, \mathrm{p}=0.642)$. The serum ALT level detected was significantly higher in diabetic patients (T2DM= $30.74 \pm 30.73 \mathrm{U} / \mathrm{L}$, Control=19.95 \pm $\left.12.12 \mathrm{U} / \mathrm{L}, \mathrm{p}=0.037^{*}\right)$. The serum HDL level detected was significantly lower (T2DM= $46.80 \pm 21.36 \mathrm{mg} / \mathrm{dL}$, Control $\left.=64.35 \pm 33.61 \mathrm{mg} / \mathrm{dL}, \mathrm{p}=0.005^{*}\right)$, and the triglyceride level higher in diabetic patients than control group (T2DM $=242.88 \pm 195.53 \mathrm{mg} / \mathrm{dL}$, Control=138.97 $\left.\pm 59.80 \mathrm{mg} / \mathrm{dL}, \mathrm{p}=0.002^{*}\right)$.

No statistically significant difference was observed regarding serum annexin $\mathrm{V}$ (type 2 diabetic group= $9.38 \pm 8.17$, control group $=11.42 \pm 8.27 \mathrm{ng} / \mathrm{ml}, \mathrm{p}=0.253$ ) and anti-annexin $\mathrm{V}$ (type 2 diabetic group $=63.10 \pm$ 43.13 , control group $=54.08 \pm 28.93 \mathrm{ng} / \mathrm{ml}, \mathrm{p}=0.258$ ) between the two groups.

Demographic and laboratory data of the patients in the two groups were compared using the t-test for independent variables. The gender distribution 
between the two groups was compared with the chisquare test.

TABLE 1. COMPARISON OF DEMOGRAPHIC AND LABORATORY DATA OF PATIENTS NEWLY DIAGNOSED WITH TYPE 2 DIABETES AND NON-DIABETIC INDIVIDUALS IN THE CONTROL GROUP.

\begin{tabular}{|c|c|c|c|}
\hline Variables & $\begin{array}{l}\text { Tip } 2 \text { DM } \\
\mathrm{n}=143\end{array}$ & $\begin{array}{l}\text { Control } \\
n=133\end{array}$ & $\mathrm{~Pa}$ \\
\hline Age, year & $50.41 \pm 8.62$ & $48.79 \pm 7.25$ & 0.346 \\
\hline Gender, F/M & $20 / 23$ & $26 / 17$ & 0,280 \\
\hline $\mathrm{BMI}, \mathrm{kg} / \mathrm{m} 2$ & $28.80 \pm 4.36$ & $26.96 \pm 4.84$ & 0.068 \\
\hline Waist Circumference, $\mathrm{cm}$ & $99.34 \pm 10.54$ & $91.37 \pm 11.63$ & $0.001^{*}$ \\
\hline $\begin{array}{l}\text { Systolic Blood Pressure, } \\
\mathrm{mmHg}\end{array}$ & $116.97 \pm 9.82$ & $114.65 \pm 16.08$ & 0.421 \\
\hline $\begin{array}{l}\text { Diastolic Blood Pressure, } \\
\mathrm{mmHg}\end{array}$ & $71.62 \pm 6.42$ & $70.46 \pm 11.53$ & 0.566 \\
\hline $\mathrm{HbA1C}, \%$ & $9.49 \pm 3.15$ & $5.42 \pm 0.26$ & $<0.001^{\star}$ \\
\hline Fasting Glucose,mg/dL & $203.95 \pm 92.03$ & $91.41 \pm 9.39$ & $<0.001^{\star}$ \\
\hline OGTT 2. hour, mg/dL & $246.36 \pm 57.09$ & $120.74 \pm 20.92$ & $<0.001 *$ \\
\hline Fasting Insulin, $\mu \mathrm{IU} / \mathrm{mL}$ & $23.47 \pm 45.64$ & $7.56 \pm 6.50$ & $0.031^{*}$ \\
\hline HOMA-IR & $10.06 \pm 16.04$ & $1.70 \pm 1.44$ & $0.002^{*}$ \\
\hline CIMT, mm & $0.81 \pm 0.19$ & $0.67 \pm 0.11$ & $<0.001^{\star}$ \\
\hline hs-CRP, mg/dL & $6.62 \pm 5.98$ & $4.08 \pm 4.29$ & $0.027^{\star}$ \\
\hline Annexin-5, ng/ml & $9.38 \pm 8.17$ & $11.42 \pm 8.27$ & 0.253 \\
\hline Anti-annexin-5, ng/ml & $63.10 \pm 43.13$ & $54.08 \pm 28.93$ & 0.258 \\
\hline Creatinine, $\mathrm{mg} / \mathrm{dL}$ & $0.90 \pm 0.16$ & $0.88 \pm 0.17$ & 0.642 \\
\hline Urea, mg/dL & $28.76 \pm 9.80$ & $28.11 \pm 8.63$ & 0.745 \\
\hline$A L T, U / L$ & $30.74 \pm 30.73$ & $19.95 \pm 12.12$ & $0.037^{\star}$ \\
\hline AST, U/L & $25.31 \pm 17.56$ & $21.28 \pm 5.70$ & 0.159 \\
\hline Total cholesterol, mg/dL & $229.33 \pm 36.66$ & $223.93 \pm 52.85$ & 0.583 \\
\hline $\mathrm{HDL}, \mathrm{mg} / \mathrm{dL}$ & $46.80 \pm 21.36$ & $64.35 \pm 33.61$ & $0.005^{*}$ \\
\hline $\mathrm{LDL}, \mathrm{mg} / \mathrm{dL}$ & $156.13 \pm 35.01$ & $142.03 \pm 45.69$ & 0.112 \\
\hline Triglycerides, mg/dL & $242.88 \pm 195.53$ & $138.97 \pm 59.80$ & $0.002^{*}$ \\
\hline
\end{tabular}

Data were expressed as mean \pm standard deviation. $P<0.05$ was considered significant.

\section{DISCUSSION}

Annexin $\mathrm{V}$ deficiency has been shown to cause hypercoagulability and hence, cardiovascular events in newly conducted studies. Diabetes is a major health problem all over the World, and cardiovascular morbidity and mortality are also observed in more than half of these patients. We investigated the levels of annexin $\mathrm{V}$ in patients newly diagnosed with type 2 diabetes. We did not detect any statistically significant difference regarding the serum annexin $\mathrm{V}$ level between the Dm group and the control. Interestingly, although no difference was detected in terms of serum annexin $\mathrm{V}$ level, a statistically significant and positive correlation was found between CIMT and the level of serum annexin $\mathrm{V}$.
Increased CIMT has been shown to be closely associated with various microvascular events such as MI and stroke, particularly in patients with Type 2 DM, in many studies in the literature. CIMT was found to be higher in Type 2 diabetics compared to control groups in a study of Temelkova-Kurktschiev et al.8, which was found to be associated with microvascular complications. CIMT, as expected, was found to be significantly higher in the diabetic group than in the healthy control group in our study. A significant relationship was also detected between CIMT and ANV level. As CIMT increased, serum ANV level increased. We have interpreted this relationship as a reactive ANV elevation for cardioprotection.

ANV and heparin have been compared in coagulation studies in rabbits. According to this, ANV inhibits fibrin production and platelet aggregation safely and quickly9. In another study, ANV was detected to be bound quickly to PSA positive platelet, red blood cells, and microparticles in a surprisingly formed $\operatorname{clot}^{10}$. The study conducted by Bakar et al. compares both serum levels of ANV and a ANVa of type 1 diabetic patients with normal healthy individuals ${ }^{11}$. The study reported that serum ANV levels were significantly lower in the type 1 diabetic patient group compared to the healthy control group, and serum a ANVa levels (both IgG and IgM) were significantly higher in the type 1 diabetic group than in the healthy control group11. In our study, when serum ANV and a ANVa levels of diabetic patients were compared with the control group, no statistically significant difference was found. The reason for this disparity in results between the two studies may be explained by antibody development against ANV caused by an autoimmune process. Based on the results of our study, we believe that there is no effect of ANV in increased atherosclerosis and hypercoagulopathy in type 2 diabetics.

ANV is known to have an anti-inflammatory role. A statistically significant relationship was found between ANV and hs-CRP, an inflammatory marker, in our study. Similarly, we assessed this relationship as the reactive increase of ANV in parallel to the increase of inflammation.

Hyperglycemia leads to the formation of free radicals, directly and indirectly, by increasing the load of free fatty acids. This is known as the initiator of a process that triggers many adverse metabolic pathways, increases the vascular permeability, reduces the fibrinolytic activity, and triggers inflammation. Inflammation has recently been associated with 
atherosclerosis, type $2 \mathrm{DM}$, and cancer. Although inflammation is a normal response to infection and tissue damage, it may have a pathological nature if the response is excessive or continuous. Numerous studies have shown that there was a strong positive association between obesity and hs-CRP12,13 and weight loss resulted in the reduction of hs-CRP concentration $^{14,15}$. A causal relationship between obesity and CRP has also been supported by recent laboratory evidence. Adipocytes and monocyte-derived macrophages in enlarged adipose tissue masses increase the synthesis of CRP in the liver by secreting proinflammatory cytokines, such as TNF- $\alpha$ and IL- $6^{16}$. The increase in hs-CRP is also observed in the presence of metabolic syndrome, in which metabolic abnormalities, including glucose intolerance, hypertriglyceridemia, and hypertension, are seen together. This condition, in which the central obesity is the main component, increases cardiovascular disease as well as type 2 diabetes risks ${ }^{17}$. It has been shown that as the number of abnormal metabolic properties increases, the CRP level elevates progressively in different populations ${ }^{18,19}$. In our study, serum hs-CRP levels were found to be statistically significantly higher in the group of patients newly diagnosed with type 2 diabetes, in comparison to the normoglycemic control group. This result also supports the relationship between hs-CRP and clinical disorders such as diabetes, atherosclerosis, and metabolic syndrome.

\section{CONCLUSION}

No difference was found between patients newly diagnosed with type 2 diabetes and the normoglycemic individuals of the control group regarding serum annexin $\mathrm{V}$ levels. These data suggest that annexin $\mathrm{V}$ has no role in the high incidence of cardiovascular events and hypercoagulopathy in type 2 diabetic patients. A positive relationship was observed between CIMT and annexin V in our study. In this regard, we also believe that serum annexin $\mathrm{V}$ levels may be increased in CIMT increase for cardioprotection.

\section{Author Contributions}

Study conception and design: Oktay Bilgir; Acquisition of data: Huseyin Afsin Vural; Analysis and interpretation of data: Ismail Demir; Drafting of the manuscript: Ozden Yildirim Akan; Critical revision: Oktay Bilgir.

\section{RESUMO}

OBJETIVO: Investigar os níveis séricos de anexina V e antianexina V e sua relação com os parâmetros metabólicos em pacientes diabéticos tipo 2 recém-diagnosticados.

MÉTODOS: Foram incluídos no estudo 143 pacientes e 133 controles com diabetes tipo 2 recém-diagnosticado. O índice de massa corporal (IMC), PCR-as, Homa-IR, espessura íntima média carotídea e níveis séricos de anexina V e antianexina V foram investigados.

RESULTADOS: O Homa-IR, a PCR-s do soro e a espessura média da carótida foram estatisticamente significantes. A análise de correlação de Pearson revelou uma relação positiva estatisticamente significante entre a espessura média da carótida e anexina $V(r=0,29$; $p=0,006$ *). Foi também detectada uma relação positiva estatisticamente significativa entre o nível de anexina $V$ e o nível sérico de $P C R$-as $\left(r=0,29, p=0,006^{*}\right)$.

CONCLUSÃo: Também foi observada uma relação positiva entre a espessura média da carótida e anexina $V$ no final da nossa investigação. A esse respeito, também pensamos que os níveis séricos de anexina $V$ podem ser aumentados para proteção cardiovascular na elevação da espessura média da carótida.

PALAVRAS-CHAVE: Diabetes mellitus tipo 2. Anexina A5. Espessura íntima média carotídea. 


\section{REFERENCES}

1. Andree HA, Stuart MC, Hermens WT, Reutelingsperger CP, Hemker HC Frederik PM, et al. Clustering of lipid bound annexin $\mathrm{V}$ may explain its anticoagulant effect. J Biol Chem. 1992;267(25):17907-12.

2. van Heerde WL, Poort S, van't Veer C, Reutelingsperger CP, Groot PG. Binding of recombinant annexin $\vee$ to endothelial cells: effect of annexin $\checkmark$ binding on endothelial-cell-mediated thrombin formation. Biochem $)$. 1994;302 (Pt 1):305-12.

3. Nakamura N, Shidara Y, Kawaguchi N, Azuma C, Mitsuda N, Onishi S, et al. Lupus anticoagulant autoantibody induces apoptosis in umbilical vein endothelial cells: involvement of annexin V. Biochem Biophys Res Commun. 1994;205(2):1488-93.

4. Sugiura $K$, Muro Y. Anti-annexin $V$ antibodies and digital ischemia in patients with scleroderma. J Rheumatol. 1999;26(10):2168-72.

5. Lakos G, Kiss E, Regeczy N, Tarjan P, Soltesz P, Zeher M, et al. Antiprothrombin and antiannexin $\mathrm{V}$ antibodies imply risk of thrombosis in patients with systemic autoimmune diseases. J Rheumatol. 2000;27(4):924-9.

6. Darabian S, Hormuz M, Latif MA, Pahlevan S, BudoffMJ. The role of carotid intimal thickness testing and risk prediction in the development of coronary atherosclerosis. Curr Atheroscler Rep. 2013;15(3):306.

7. Stein JH, Korcarz CE, Hurst RT, Lonn E, Kendall CB, Mohler ER, et al; American Society of Echocardiography Carotid Intima-Media Thickness Task Force. Use of carotid ultrasound to identify subclinical vascular disease and evaluate cardiovascular disease risk: a consensus statement from the American Society of Echocardiography Carotid Intima-Media Thickness Task Force. Endorsed by the Society for Vascular Medicine. J Am Soc Echocardiogr. 2008;21(2):93-111.

8. Temelkova-Kurktschiev TS, Koehler C, Leonhardt W, Schaper F, Henkel E, Siegert $\mathrm{G}$, et al. Increased intimal-medial thickness in newly detected type 2 diabetes: risk factors. Diabetes Care. 1999;22(2):333-8.
9. Thiagarajan $P$, Benedict $C R$. Inhibition of arterial thrombosis by recombinant annexin $\mathrm{V}$ in a rabbit carotid artery injury model. Circulation. 1997;96(7):2339-47.

10. Van Ryn-McKenna I, Merk H, Müller TH, Buchanan MR, Eisert WG. The effects of heparin and annexin $V$ on fibrin accretion after injury in the jugular veins of rabbits. J Thromb Haemost. 1993;69(3):227-30.

11. Bakar F, Unlütürk U, Başkal N, Nebioğlu S. Annexin $V$ expression and anti-annexin $\mathrm{V}$ antibodies in type 1 diabetes. | Clin Endocrinol Metab. 2014;99(3):932-7.

12. Visser M, Bouter LM, McQuillan GM, Wener MH, Harris TB. Elevated $C$-reactive protein levels in overweight and obese adults. JAMA 1999;282(22):2131-5.

13. Timpson NJ, Lawlor DA, Harbord RM, Gaunt TR, Day IN, Palmer LJ, et al. C-reactive protein and its role in metabolic syndrome: mendelian randomisation study. Lancet. 2005;366(9501):1954-9.

14. Dietrich $M$, Jialal I. The effect of weight loss on a stable biomarker of inflammation, C-reactive protein. Nutr Rev. 2005;63(1):22-8.

15. Selvin E, Paynter NP, Erlinger TP. The effect of weight loss on C-reactive protein: a systematic review. Arch Intern Med. 2007;167(1):31-9.

16. Eckel RH, Grundy SM, Zimmet PZ. The metabolic syndrome. Lancet. 2005;365(9468):1415-28.

17. Fröhlich M, Imhof A, Berg G, Hutchinson WL, Pepys MB, Boeing H, et al. Association between $C$-reactive protein and features of the metabolic syndrome: a population-based study. Diabetes Care. 2000;23(12):1835-9.

18. Ridker PM, Buring JE, Cook NR, Rifai N. C-reactive protein, the metabolic syndrome, and risk of incident cardiovascular events: an 8-year follow-up of 14719 initially healthy American women. Circulation. 2003;107(3):391-7.

19. Choi EY, Park EH, Cheong YS, Rheem I, Park SG, Yoo S. Association of C-reactive protein with the metabolic risk factors among young and middle-aged Koreans. Metabolism. 2006;55(3):415-21. 